\title{
ZASADY ODBIORU I GOSPODAROWANIA ODPADAMI KOMUNALNYMI NA GRUNCIE ZNOWELIZOWANEJ USTAWY O UTRZYMANIU CZYSTOŚCI I PORZĄDKU W GMINACH
}

\section{PRINCIPLES OF RECEIVING AND MUNICIPAL WASTE MANAGEMENT ON THE BASIS OF THE AMENDED ACT ON MAINTAINING CLEANLINESS AND ORDER IN MUNICIPALITIES}

\footnotetext{
STRESZCZENIE

Artykuł dotyczy kwestii nowych regulacji w zakresie odbioru i gospodarowania odpadami komunalnymi przed podmioty gospodar-

* Doktorantka w Zakładzie Prawa Ochrony Środowiska i Nauki Administracji Publicznej Wydziału Prawa Uniwersytetu w Białymstoku.
} 
cze, zawartych w nowelizacji ustawy o utrzymaniu czystości i porządku w gminach, która weszła w życie dnia 1 stycznia 2012 r. Celem artykułu jest zwięzłe porównanie dotychczasowych przepisów ustawy z nowymi przepisami, pod kątem obowiązków gospodarowania odpadami komunalnymi nałożonych na gminę m.in. wyboru podmiotu gospodarczego odpowiedzialnego za odbiór i gospodarowanie odpadami, określenie wysokości opłaty za gospodarowanie odpadami uiszczanej przez właścicieli nieruchomości itp. Autorka wskazuje pozytywne unormowania, ale także kontrowersyjne czy też niejasne rozwiązania prawne wprowadzone przez ustawodawce na gruncie znowelizowanej ustawy. Zamierzeniem autorki artykułu jest ukazanie mechanizmu funkcjonowania nowego modelu gospodarki odpadami komunalnymi oraz wskazanie możliwych skutków nowych regulacji. Autorka odwołuje się także do dotychczasowego modelu gospodarowania odpadami komunalnymi, ukazując następstwa poprzednich unormowań.

\title{
Słowa kluczowe
}

Odpady komunalne, gmina, właściciele nieruchomości, gospodarka odpadami, podmioty gospodarcze.

\begin{abstract}
The article relates to issues of new regulations regarding receive and municipal waste management by business entity, contained in the amended Act on maintaining cleanliness and order in municipalities, which entered into force on the 1st January 2012. The purpose of this article is a brief comparison of current regulations of the Act with the new rules in terms of waste management obligations imposed on the municipality, includes the choice of the business entity responsible for the receiving and management of waste, determination of waste management fees paid by property owners, etc. The author points out the positive norms, but also controversial or vague legal provisions made by the legislature on the basis of the amended Act. The intention of the author of the article is to present a new model for the mechanism of functioning of the municipal waste management and to indicate the possible effects of the new regulations. The author also refers to the current waste management model, showing the consequences of previous regulations.
\end{abstract}


Keywords

Municipal waste, municipality, property owners, waste management, business entity.

Nadchodzące kilka lat będzie dla Polski kluczowe w kwestii stworzenia skutecznego i sprawnie działającego systemu gospodarowania odpadami. Zbliżają się bowiem terminy, jakie Unia Europejska wyznaczyła na spełnienie nałożonych dyrektywami zobowiązań. Jednym z trzech głównych zadań w tym zakresie jest ograniczenie ilości produkowanych odpadów komunalnych oraz zorganizowanie zgodnego z przyjętą przez Unię hierarchią postępowania z odpadami oraz systemu zbierania i zagospodarowania odpadów wytworzonych. Zgodnie z polityką Unii właściwe gospodarowanie odpadami pozwala na urzeczywistnienie zasad zrównoważonego rozwoju ${ }^{1}$. Są to więc takie działania organów administracji, które umożliwiają zachowanie równowagi przyrodniczej m.in. poprzez wprowadzenie nowych technologii i rozwiązań prawnych, które sprawdziły się już w państwach posiadających rozwinięty mechanizm ochrony środowiska. We wspomnianej hierarchii postępowania z odpadami na pierwszym miejscu znajduje się zapobieganie powstawaniu odpadów, jeżeli nie jest to możliwe, to przygotowanie odpadów do ich ponownego użycia, następnie poddanie procesom recyklingu bądź innym metodom odzysku, a ostatecznie unieszkodliwiane ${ }^{2}$. Określona przepisami unijnymi hierarchia postępowania $\mathrm{z}$ odpadami stanowi również odzwierciedlenie zasady przezorności i prewencji, zawartej w art. 6 ustawy Prawo ochrony środowiska ${ }^{3}$. Ustawa nakłada na podmioty, z których działalnością wiąże się możliwość powstawania odpadów, obowiązek podejmowania wszelkich działań mających na celu zapobieganie powstawaniu odpadów ${ }^{4}$.

1 A. Gabryś, D. Sudomir, Kluczowe wyzwania w gospodarce odpadami komunalnymi w krajach UE-11, Raport Ernst\&Young, Warszawa 2011, s. 6.

2 Ibidem.

3 Ustawa z dnia 27 kwietnia 2001 r. Prawo ochrony środowiska, tj. Dz. U. 2008 r. Nr 25, poz. 150 ze zm.

4 J. Stelmasiak (red.), Prawo ochrony środowiska, Warszawa 2009, s. 30 
Przed przejściem do sedna problematyki gospodarowania odpadami komunalnymi niezbędne jest przytoczenie kilku faktów z ową tematyką związanych. Na mocy dyrektywy Parlamentu Europejskiego i Rady 2008/98/WE z dnia 19 listopada 2008 r. w sprawie odpadów (tzw. dyrektywa ramowa/dyrektywa odpadowa) ${ }^{5}$ Polska do dnia 12 grudnia 2013 r. ma obowiązek opracowania planów gospodarki odpadami oraz zintegrowanych z nimi programów zapobiegania powstawaniu odpadów. Co więcej do 2020 r. Polska powinna zapewnić, aby 50\% odpadów komunalnych, przynajmniej takich jak papier, metal, plastik i szkło zostało poddane przygotowaniu do ponownego wykorzystania i recyklingowi. Niewywiązanie się z tych zobowiązań skutkować będzie postępowaniem w Trybunale Sprawiedliwości UE oraz wysokimi karami pieniężnymi ${ }^{6}$.

W związku więc ze zbliżającymi się terminami, organy ustawodawcze podjęły intensywne działania w celu zmiany istniejącego do niedawna, nieefektywnego systemu gospodarowania odpadami komunalnymi, a odzwierciedleniem tego jest znowelizowana (z dniem 1 stycznia 2012 r.) ustawa z dnia 13 września 1996 r. o utrzymaniu czystości i porządku w gminach? Nowelizacja wprowadziła tak daleko idące zmiany, iż stanowi swego rodzaju rewolucję i w praktyce wprowadza nowy model zarządzania odpadami komunalnymi.

Aby zobrazować skalę i znaczenie dla funkcjonowania gospodarki odpadami wprowadzonych w ustawie zmian, należy przybliżyć w sposób przekrojowy dotychczas funkcjonujący model gospodarowania odpadami komunalnymi. W pierwszej kolejności podkreślenia wymaga fakt, iż zarówno przed nowelizacją ustawy, jak i obecnie, utrzymanie czystości i porządku w gminach, które w istocie oznacza zagwarantowanie sprawnej i prawidłowej gospodarki odpadami komunalnymi, jest zadaniem gminy. Co natomiast odróżnia w głównej mierze aktualne ustawodawstwo od poprzedniego to mechanizm zarzą-

5 Dz. Urz. UE L 312 z 22.11.2008, s. 3.

6 A. Gabryś, D. Sudomir, Kluczowe wyzwania $w$ gospodarce odpadami komunalnymi $w$ krajach UE-11, Raport Ernst\&Young, Warszawa 2011, s. 40.

7 T.j. Dz. U. z 2012 r., poz. 391; dalej cyt.: u.c.p.g. 
dzania odpadami. Gospodarka odpadami oparta była bowiem o samodzielne działania wytwórców odpadów, co oznacza, iż to wytwórcy odpadów zawierali umowy z podmiotami gospodarczymi, które świadczyły usługi w zakresie odbioru i dalszego gospodarowania odpadami. Zgodnie z art. 3 pkt 22 ustawy z dnia 27 kwietnia 2001 r. o odpadach ${ }^{8}$ przez wytwórce odpadów rozumie się każdego, którego działalność lub bytowanie powoduje powstanie odpadów oraz każdego kto przeprowadza wstępne przetwarzanie, mieszanie lub inne działania powodujace zmiane charakteru lub składu tych odpadów. Dokonując wykładni tej definicji na gruncie regulacji dotyczących odpadów komunalnych należy stwierdzić, iż mowa tu o właścicielach nieruchomości, którzy produkują odpady komunalne, i którzy na gruncie dotychczasowej ustawy o utrzymaniu czystości i porządku w gminach zobowiązani byli do tego, aby na własną odpowiedzialność zająć się organizacją odbioru odpadów przez dany podmiot gospodarczy (ówczesny art. 5 ust. 1 pkt. 3b u.c.p.g.). Natomiast podmioty gospodarcze prowadzące działalność w zakresie odbioru i dalszego gospodarowania odpadami działały na zasadach konkurencyjności, urzeczywistniając tym samym zasady wolnego rynku. Pozytywnymi aspektami ówczesnej regulacji było z pewnością to, iż właściciele nieruchomości dysponowali możliwością wyboru najlepszej ich zdaniem oferty, a duże rzesze przedsiębiorców miało szansę na prowadzenie działalności gospodarczej w oparciu o zasady wolnej konkurencji, co stanowiło czynnik wpływający pozytywnie na rozwój gospodarki. Rola gminy w gospodarce odpadami komunalnymi ograniczała się do administracyjnej kontroli przedsiębiorców i gminnych jednostek działających w warunkach swobody gospodarczej. Owe władztwo administracyjne przejawiało się w kompetencjach gminy do określania podstawowych warunków świadczenia usług oraz kontroli prawidłowości postępowania mieszkańców i przedsiębiorców ${ }^{9}$. Trzeba jednak zaznaczyć, iż ustawa oferowała mieszkańcom możliwość wyboru innego

8 T.j. Dz. U. z 2010 r. Nr 185, poz. 1243 ze zm.

9 B. Wierzbowski, B. Rakoczy, Prawo ochrony środowiska, Warszawa 2010, s. 304-307. 
modelu gospodarowania odpadami, mieszkańcy mogli bowiem w drodze referendum zdecydować o tym, iż to gmina przejmuje ich obowiązki i ustanawia stosowną opłatę za odbiór i gospodarowanie odpadami. Stanowił o tym art. 6a ustawy, który wyraźnie upoważniał radę gminy do przyjęcia uchwały, na mocy której to gmina podejmowałaby wskazane czynności.

Zaakcentowania wymaga fakt, iż koncepcja gospodarowania odpadami komunalnymi, jak pokazuje historia, nigdy nie była całościowo dopracowana, co powodowało liczne i niespójne nowelizacje - na początku w ustawie o odpadach a następnie w ustawie o zachowaniu czystości i porządku w gminach ${ }^{10}$. $\mathrm{W}$ gruncie rzeczy już od wielu lat prace legislacyjne oscylują głównie wokół aspektu samodzielności gminy w kreowaniu i zarządzaniu systemem gospodarowania odpadami, bowiem to właśnie gmina była i jest odpowiedzialna za tę działalność. Wyrazem tego jest art 3 u.c.p.g., który stanowi, iż utrzymanie czystości i porzadku $w$ gminach jest obowiazkowym zadaniem własnym gminy. Dylemat ustawodawcy na przestrzeni ostatnich 20 lat polegał na tym, czy usytuować jednostki organizacyjne gminy wśród podmiotów prywatnych i zapewnić funkcjonowanie systemu gospodarowania odpadami komunalnymi w warunkach wolnej konkurencji, czy też ograniczyć tę konkurencję na rzecz stworzenia kompleksowego systemu zarządzanego tylko przez gminę. Następowało tu więc starcie przeciwstawnych wartości. Rozwiązaniem optymalnym było pozostawienie wyboru metody gospodarowania mieszkańcom gminy, poprzez wspomniane referendum, i ustalenie opłaty za gospodarowanie odpadami, jednak w praktyce mieszkańcy większości gmin nie przejawiali woli rozwiązania istniejących problemów właśnie $\mathrm{w}$ ten sposób ${ }^{11}$. Powodem tego mógł być m.in. brak zaufania do władzy bądź zbyt niska świadomość społeczna w kwestii potrzeby zajęcia się problemem odpadów komunalnych. Na dzień dzisiejszy to prawo unijne stało się czynnikiem, który zdetermino-

10 J. Jerzmański, Gospodarka odpadami komunalnymi - nowe zasady, „Przegląd Komunalny” nr 9/2011.

11 Ibidem. 
wał i zobligował ustawodawcę do podjęcia stosownych zmian, nakładając wymóg implementacji dyrektywy ramowej.

System istniejący do 2012 r. wydawał się pod wieloma aspektami korzystny jednak praktyka pokazywała, iż tak skonstruowany model gospodarki odpadami powodował liczne problemy i części gmin uniemożliwiał sprawną organizację gospodarowania odpadami komunalnymi. Przede wszystkim, dotychczas obowiązujące przepisy nie dawały gminie możliwości realnego egzekwowania płacenia za odpady komunalne czy ich właściwego, zgodnego z prawem gospodarowania ${ }^{12}$. Sytuacja ta spowodowana była brakiem odpowiedniego nadzoru nad działalnością przedsiębiorców, którzy w celu uchylenia się od płacenia podatków nielegalnie wywozili część odpadów w niedozwolone miejsca bądź zawierali umowy bez wymaganych zezwoleń na prowadzenie działalności ${ }^{13}$. Istniejący stan prawny wykorzystywali również wytwórcy odpadów, którzy w celu zmniejszenia kosztów związanych z odbiorem i transportem odpadów, części $\mathrm{z}$ nich pozbywali się $\mathrm{w}$ miejscach do tego nie przeznaczonych np. w lasach. W efekcie odpady były nielegalnie wyrzucane w przypadkowo wybrane obszary, zatruwając glebę i wody podziemne. Dotychczas obowiązujący system składowania odpadów okazał się więc „nieszczelny”, bowiem duży odsetek ilości odpadów trafiał do środowiska w sposób nieewidencjonowany i niezgodny z regulacjami unijnymi. Przypuszczalnie niezebrane odpady w większości trafiały na dzikie wysypiska lub były utylizowane - najczęściej spalane - przez mieszkańców we własnym zakresie $^{14}$. Zgodnie z przeprowadzonymi badaniami ok. 1/6 wytwarzanych odpadów trafia rokrocznie do środowiska w sposób nieewidencjonowany ${ }^{15}$.

Niezbędne stało się więc wprowadzenie zmian $\mathrm{w}$ tym zakresie. Pierwszą, istotną zmianą jest przejęcie przez gminy

12 J. Zyśk, Rewolucja następuje powoli, „Odpady i środowisko”, nr 1/2011.

13 D. Olszewska, Kontrola $w$ nielegalne składowiska? Na razie porażka, www.gazeta.pl/warszawa z dnia 21.11.2012 r.

14 J. Zyśk, Czy gminy będa $w$ stanie zapanować nad odpadami?, „Prawo i Odpady", nr 4/2011.

15 A. Gabryś, D. Sudomir, Kluczowe wyzwania, s. 46. 
obowiązku organizacji odbioru odpadów. Zgodnie z nowymi przepisami obowiązek ten wynika ex lege z przepisów prawa (art. 6c ust. 1 u.c.p.g.), jednak istnieje on tylko w stosunku do właścicieli nieruchomości, na których zamieszkują mieszkańcy. W tym zakresie gmina ma obowiązek wyboru podmiotu, który będzie odbierał od mieszkańców gminy odpady komunalne oraz zawarcia z nim stosownej umowy. Z kolei właściciele nieruchomości, na których zamieszkują mieszkańcy, są z mocy prawa zobowiązani do ponoszenia na rzecz gminy opłaty za gospodarowanie odpadami komunalnymi. Zgodnie z ustaloną przez poszczególne gminy opłatą, każdy mieszkaniec ma obowiązek zapłaty za odbiór śmieci, czyli wszystkich komunalnych odpadów, które wyprodukuje, w tym wielkogabarytowych. Stawka opłaty określana jest na podstawie: liczby mieszkańców zamieszkujących daną gminę, ilości wytwarzanych na terenie gminy odpadów komunalnych, kosztów funkcjonowania systemu gospodarowania odpadami, przy uwzględnieniu przypadków, w których właściciele nieruchomości wytwarzają odpady nieregularnie, a w szczególności tego, że na niektórych nieruchomościach odpady komunalne powstają sezonowo (art. 6k ust. 2 u.c.p.g.). Ponadto rada gminy może, w drodze uchwały stanowiącej akt prawa miejscowego, postanowić o odbieraniu odpadów komunalnych od właścicieli nieruchomości, na których nie zamieszkują mieszkańcy, a powstają odpady komunalne (art. 6c ust. 2 u.c.p.g.). W razie podjęcia takiej uchwały mamy do czynienia z jednolitym systemem odbioru - dla wszystkich właścicieli nieruchomości, co dotychczas było możliwe jedynie po przeprowadzeniu referendum.

Pierwszą kwestią, która wymaga omówienia jest zdefiniowanie pojęcia „mieszkańca zamieszkującego daną nieruchomość". Jest to zagadnienie ważne z punktu widzenia obowiązku określenia przez gminę wysokości stawki za gospodarowanie odpadami. Tutaj pojawia się pierwsza wątpliwość i pytanie, na jakiej podstawie organ gminy powinien szacować liczbę mieszkańców, aby w rzetelny i sprawiedliwy sposób określić wysokość opłaty za gospodarowanie odpadami. W pierwszej kolejności należy rozstrzygnąć, czy ustawodawca interpretuje „mieszkań4/2012 ca” jako osobę posiadającą w danej gminie „miejsce zamiesz- 
kania” czy ewentualnie „miejsce zameldowania”, a być może jeszcze $\mathrm{w}$ inny sposób. Definicja miejsca zamieszkania osoby fizycznej zawarta jest w art. 25 Kodeksu cywilnego ${ }^{16}$, który stanowi, iż miejscem zamieszkania osoby fizycznej jest miejscowość, $w$ której osoba ta przebywa z zamiarem statego pobytu. Kodeks wyraźnie więc definiuje miejsce zamieszkania jako miejscowość, a nie ściśle określoną nieruchomość, która funkcjonuje jako lokal mieszkalny. Drugi człon przepisu wskazuje natomiast, że osoba przebywająca w danej miejscowości musi cechować się wolą pozostania $\mathrm{w}$ danym miejscu na czas bliżej nieokreślony, co w przedmiotowej sytuacji nie jest warunkiem koniecznym do nałożenia opłaty, wystarczającym jest bowiem samo przebywanie na danej nieruchomości, zarówno stałe jak i czasowe.

Kolejną instytucją prawną, którą potencjalnie mógł posłużyć się ustawodawca, jest obowiązek meldunkowy, wynikający z ustawy z dnia 10 kwietnia 1974 r. o ewidencji ludności i dowodach osobistych ${ }^{17}$. Przyjęcie tego wariantu umożliwiłoby ustalenie faktu zamieszkania na danej nieruchomości za pomocą dokumentu meldunkowego. Jednakże w tym miejscu, analizy wymaga kierunek postępowania ustawodawcy i cel, jaki powinien być osiągnięty za pomocą nowej ustawy o utrzymaniu czystości i porządku w gminie. Zaznaczyć należy, iż intencją ustawodawcy było obciążenie stosownymi kosztami podmioty, które rzeczywiście odpady wytwarzają, proporcjonalnie do ilości wyprodukowanych odpadów. Decydujące jest tu więc swoiste bytowanie osób na danej nieruchomości, które wiąże się z powstawaniem odpadów. Natomiast, meldunek oznacza jedynie rejestrację przez odpowiedni organ administracji stanu faktycznego na określonym administracyjnie obszarze i służy prawidłowemu wykonywaniu funkcji przez organy administracji publicznej ${ }^{18}$. Ponadto należy mieć na uwadze, iż znaczna liczba osób nie dopełnia obowiązku meldunkowego, a więc fakt

16 Ustawa z dnia 23 kwietnia 1964 r. Kodeks cywilny, Dz. U. z 1964 r. Nr 16, poz. 93 ze zm.

17 T.j. Dz. U. z 2006 r. Nr 139, poz. 993 ze zm.

18 Wyrok Trybunału Konstytucyjnego z dnia 27 maja 2002 r. sygn. akt K 20/01, OTK ZU 2002, nr 3A, poz. 34. 
zameldowania nie przesądza o faktycznym miejscu zamieszkania danej osoby. Co więcej zgodnie z brzmieniem art. 74 ust. 1 nowej ustawy o ewidencji ludności ${ }^{19}$, która została uchwalona dnia 24 września 2010 r., od dnia 1 stycznia 2014 r. znosi się obowiązek meldunkowy, co przesądza o tym, iż miejsce zameldowania nie powinno być czynnikiem będącym podstawą obliczania opłaty za gospodarowanie odpadami.

Analizę zamyka regulacja zawarta w przepisie art. $2 \mathrm{~d}$ rozporządzenia WE nr 763/2008 z dnia 9 lipca 2008 r. w sprawie spisów powszechnych ludności i mieszkań ${ }^{20}$, która definiuje miejsce zamieszkania jako miejsce w którym osoba zazwyczaj spedza czas przeznaczony na odpoczynek, niezaleznie od czasowych nieobecności zwiazanych z wypoczynkiem, urlopem, odwiedzinami u przyjaciót i krewnych, interesami, leczeniem medycznym lub pielgrzymkami religijnymi. Wydaje się więc, iż jest to najbardziej trafny opis mieszkańca na gruncie ustawy o utrzymaniu czystości i porządku w gminie i jak postulują praktycy, to ta interpretacja powinna być przyjęta przy obliczaniu wysokości opłaty za gospodarowanie odpadami ${ }^{21}$.

Kolejnym zagadnieniem budzącym wątpliwości i kontrowersje jest określony $\mathrm{w}$ ustawie sposób obliczania opłaty. Zgodnie z art. 6j ust. 1 u.c.p.g. opłata za gospodarowanie odpadami komunalnymi stanowi iloczyn stawki opłaty ustalonej uchwałą rady gminy na podstawie art. 6k ust. 1 u.c.p.g. oraz: ilości mieszkańców zamieszkujących daną nieruchomość, ilości zużytej wody z danej nieruchomości, albo powierzchni lokalu mieszkalnego. Zdaniem Pracodawców RP metoda obliczania opłaty jest wadliwa ${ }^{22}$. Niejasności dotyczące pierwszej z metod

19 Ustawa z dnia 24 września 2010 r. o ewidencji ludności, Dz. U. z 2010 r. Nr 217, poz. 1427 ze zm.

20 Rozporządzenie WE nr 763/2008 z dnia 9 lipca 2008 r. w sprawie spisów powszechnych ludności i mieszkań, Dz. Urz. UE L 218 z 13.8.2008, s. $14-20$.

21 Pojęcie „mieszkańca” na gruncie ustawy o utrzymaniu czystości i porządku w gminach po nowelizacji z dnia 1 lipca 2011 r., Kancelaria Radców Prawnych Klatka i Partnerzy, http://www.prawosmieciowe.pl/ z dnia 21.11.2012 r.

22 J. Zyśk, Czy gminy będa $w$ stanie zapanować nad odpadami?, „Prawo 4/2012 i Odpady", nr 4/2011. 
zostały omówione powyżej, natomiast pozostałe metody również budzą obiekcje, bowiem według przeciwników nowych regulacji, podstawa obliczeń wydaje się nie mieć związku z aktywnością ludzką powodującą powstawanie odpadów. Tak jest choćby z obliczaniem opłaty na podstawie ilości zużytej wody $\mathrm{z}$ danej nieruchomości. Podnoszone są głosy, iż jest to metoda nieadekwatna do zakładanego celu, bowiem częstotliwość korzystania z wody nie warunkuje produkowania większej ilości śmieci. Co więcej, również kolejna podstawa obliczania, czyli powierzchnia lokalu mieszkalnego, nie jest do końca realnym wykładnikiem, bowiem nie stanowi ona o tym, ile osób zamieszkuje dany lokal, a w związku z tym, jak duża ilość odpadów jest wytwarzana. Ponadto ustawodawca nie doprecyzował, czy chodzi tu o powierzchnię mieszkalną, całkowitą czy użytkową ${ }^{23}$. Zgodnie $\mathrm{z}$ art. 6j ust. 2 u.c.p.g. rada gminy może także uchwalić jedną stawkę opłaty za gospodarowanie odpadami komunalnymi od gospodarstwa domowego. W polskim systemie prawa nie ma legalnej definicji pojęcia "gospodarstwo domowe”, doktryna i orzecznictwo starają się natomiast wskazać kryteria pozwalające stwierdzić, iż dane osoby prowadzą wspólnie gospodarstwo domowe. Można wyróżnić następujące cechy, które są charakterystyczne dla prowadzenia wspólnego gospodarstwa domowego: udział i wzajemna ścisła współpraca w załatwianiu codziennych spraw związanych z prowadzeniem domu; niezarobkowanie i pozostawanie $\mathrm{w}$ związku $\mathrm{z}$ tym na całkowitym lub częściowym utrzymaniu osoby, z którą się gospodarstwo domowe prowadzi; stałość wskazanych okoliczności ${ }^{24}$. Wskazane cechy świadczą o tym, iż ilość osób prowadząca wspólnie gospodarstwo domowe może być bardzo różna, a konsekwencją tego jest duża rozpiętość szacunkowa w ilości wytwarzanych odpadów na jedno gospodarstwo domowe. Oznacza to więc, że również i ta metoda może nie odzwierciedlać we właściwy sposób rzeczywistej ilości wytwarzanych odpadów na osobę.

23 Ibidem.

24 Wyrok WSA w Lublinie z dnia 27 listopada 2009 r., sygn. akt II SA/Lu 587/09, http://www.orzeczenia-nsa.pl 
Kontrowersyjne jest ponadto takie skonstruowanie przepisów ustawy, które nie wprowadza żadnych wyjątków w zakresie podmiotów zobowiązanych do oddawania odpadów gminie. Przytaczając treść definicji „właściciela nieruchomości” (art. 2 ust. 1 pkt 4 u.c.p.g.), przez właściciela nieruchomości rozumie się także wspótwtaścicieli, u̇̇ytkowników wieczystych, oraz jednostki organizacyjne i osoby posiadajace nieruchomości $w$ zarzadzie lub użytkowaniu, a takize inne podmioty władajace nieruchomościa. Zakres pojęcia właściciel nieruchomości, jest ujęty bardzo szeroko. Zdaniem prof. M. Chmaja, konstytucjonalisty, błędem ustawodawcy jest, iż nie wyłączył on spod tego obowiązku takich podmiotów, jak spółdzielnie czy wspólnoty mieszkaniowe, które w wielu przypadkach mają możliwości i środki zagospodarowania odpadów we własnym zakresie. Profesor Chmaj stwierdził, iż jest to zapis niezgodny z konstytucyjną zasadą wolności gospodarczej ${ }^{25}$.

Konkludując powyższy wywód, nowa ustawa z pewnością ujednolica warunki korzystania z usług podmiotu prowadzącego działalność w zakresie odbioru i zagospodarowania odpadów, co umożliwia funkcjonowanie sprawnego i opartego o jasne zasady mechanizmu gospodarowania odpadami, z drugiej jednak strony odbiera wytwórcom odpadów możliwość decydowania o tym jaki podmiot, na jakich zasadach, i za jaką opłatą będzie się tym zajmował.

Prowadzone powyżej rozważania stanowiły niejako wstęp do analizy najważniejszej kwestii związanej z rewolucyjnymi zmianami w ustawie o utrzymaniu czystości i porządku w gminie, a mianowicie do kwestii mechanizmu funkcjonowania nowego systemu gospodarowania odpadami. Obecnie to gmina przejęła faktyczną odpowiedzialność za organizację gospodarki odpadów komunalnych, co oznacza że to gmina zajmuje się organizacją systemu odbioru odpadów oraz finansową organizacją gospodarki odpadami ze środków, które pochodzą z opłat pobieranych od właścicieli. Konstytuuje to art. 3 u.c.p.g., który nakłada na gminy wymóg tworzenia warunków do wykonywania

25 J. Zyśk, Czy gminy będa w stanie zapanować nad odpadami?, „Odpady i Środowisko", nr 4/2011. 
prac związanych z utrzymaniem czystości i porządku na swoim terenie lub zapewnia wykonanie tych prac przez tworzenie odpowiednich jednostek organizacyjnych. W przypadku braku takich jednostek wykonanie prac musi być powierzone w drodze umowy podmiotowi zewnętrznemu, czyli przedsiębiorcy. Nowy model opiera sie bowiem na wyborze jednego podmiotu prowadzącego działalność w zakresie gospodarki odpadami, który wybierany jest w drodze przetargu (art. 6d u.c.p.g.). Spółki $\mathrm{z}$ udziałem gminy są traktowane identycznie jak przedsiębiorcy (art. 6e u.c.p.g.). Organem administracji odpowiedzialnym za zorganizowanie przetargu jest wójt, z kolei przedmiotem przetargu może być odbieranie odpadów bądź odbieranie i zagospodarowanie odpadów.

Zdaniem J. Jerzmańskiego opcja przetargu jest o tyle istotna, iż umowa, która następnie jest zawierana z przedsiębiorcą, pozwala na szczegółowe określenie dalszych sposobów postępowania z odpadami, co ma znaczenie z punktu widzenia wymogów prawa unijnego, jakie nakładane są na gminy. Mowa tu m.in. o obowiązkach w zakresie osiągania odpowiednich poziomów recyklingu i przygotowania do ponownego użycia niektórych frakcji odpadów komunalnych oraz ograniczenia masy odpadów komunalnych ulegających biodegradacji, przekazywanych do składowania. Wspomniane szczególne sposoby postępowania z odpadami dotyczą m.in. określenia rodzajów odpadów komunalnych odbieranych od właścicieli nieruchomości, standardu sanitarnego wykonywania usług, obowiązku prowadzenia dokumentacji itp. ${ }^{26} \mathrm{~W}$ przypadku rozwiązania umowy na odbieranie odpadów komunalnych od właścicieli nieruchomości wójt obowiązany jest niezwłocznie zorganizować nowy przetarg (art. $6 \mathrm{f}$ u.c.p.g.). W celu zapewnienia odbierania odpadów komunalnych z terenu gminy, do czasu rozstrzygnięcia przetargu, gmina zapewnia te usługi w trybie zamówienia $\mathrm{z}$ wolnej ręki, zgodnie z ustawą z 2004 r. Prawo zamówień publicznych ${ }^{27}$. Jed-

26 J. Jerzmański, Gospodarka odpadami komunalnymi - nowe zasady, „Przegląd Komunalny”, nr 9/2011.

${ }_{27}$ Ustawa z dnia 29 stycznia 2004 r. Prawo zamówień publicznych, tj. Dz. U. z 2010 r. Nr 113, poz. 759 ze zm. 
nakże, jak zostało wspomniane, alternatywę stanowi utworzenie przez gminę odpowiedniej jednostki organizacyjnej. Budzi to jednak wątpliwości na tle art. 9z ust. 4 u.c.p.g., który stanowi, iż gmina, która nie wykonuje obowiązku przeprowadzenia przetargu, podlega określonej karze pieniężnej.

Reasumując, tak zasadnicze zmiany w systemie gospodarowania odpadami wzbudziły liczne kontrowersje i dyskusje na temat celowości i prawidłowości wprowadzonych nowelizacji, na tle Konstytucji RP. Apel został podniesiony głównie ze strony przedsiębiorców, którzy zarzucili ustawodawcy naruszenie zasad wolności gospodarczej i gospodarki rynkowej, a w konsekwencji powrotu do monopolizacji i nacjonalizacji prywatnego rynku. Z pewnością nowemu systemowi gospodarowania odpadami nie brakuje zalet, bowiem przejęcie przez gminę obowiązku odbierania i gospodarowania odpadami wpłynie na zwiększenie kontroli przepływu strumienia odpadów i w dalszej perspektywie spowoduje obniżenie ilości nielegalnych wysypisk, czy wzrost poziomu segregacji odpadów ${ }^{28}$. Ponadto gminy przejmując zadania od przedsiębiorców będą miały możliwość stworzenia sprawnego i jednolitego mechanizmu odbioru i transportu odpadów w wyznaczone miejsca, a środki pieniężne uzyskane $\mathrm{z}$ opłat od właścicieli nieruchomości pozwolą na wybudowanie instalacji do przetwarzania odpadów ${ }^{29}$.

Jednakże założenia swobodnego zarządzania przez gminę odpadami spotykają sie $\mathrm{w}$ Polsce $\mathrm{z}$ barierą $\mathrm{w}$ postaci uwarunkowań rynku pracy w sektorze gospodarowania odpadami, który na przestrzeni ostatnich 20 lat był rynkiem w dużej części sprywatyzowanym, w przeciwieństwie do tego sektora gospodarki w państwach tzw. starej Unii Europejskiej. Powstaje więc pytanie czy gminy, będąc niedoświadczone w tej dziedzinie, poradzą sobie pod względem organizacyjnym, logistycznym i finansowym ${ }^{30}$.

28 J.Zyśk, W gminach po referendum, „Odpady i środowisko”, nr 2/2011.

29 J. Zyśk, Czy gminy będa $w$ stanie zapanować nad odpadami?, „Odpady i Środowisko", nr 4/2011.

30 Ibidem. 
Na ostateczną ocenę nowego modelu gospodarowania odpadami komunalnymi należy jednak poczekać przynajmniej do 1 lipca 2013 r., bowiem jest to ostateczny termin, od którego nowy system ma zacząć funkcjonować - to wtedy uchwały rad gmin wchodzą w życie, a gminy zaczynają pobierać opłaty od właścicieli nieruchomości. Do tego czasu muszą zostać rozstrzygnięte przetargi na odbieranie odpadów od właścicieli nieruchomości oraz muszą być podpisane umowy między gminą, a przedsiębiorcami ${ }^{31}$. W gruncie rzeczy efekty będą widoczne dopiero za jakiś czas, jednak już na dzień dzisiejszy kilka gmin może pochwalić sie pozytywnymi skutkami takiego sposobu zarządzania odpadami, chodzi tu m.in. o gminy, w których jeszcze na gruncie poprzedniego ustawodawstwa właściciele nieruchomości w drodze referendum przekazali obowiązki gminie. Przykładem jest gmina Pszczyn, w której ów system działa od 2008 r., i która może pochwalić się takimi sukcesami, jak odczuwalne ograniczenie spalania odpadów w piecach czy zmniejszenie liczby dzikich wysypisk śmieci. Pozostaje więc mieć nadzieję, iż pomimo pewnych niejasności czy względnego skomplikowania znowelizowanej ustawy o utrzymaniu czystości i porządku w gminie, gminy poradzą sobie z nowymi zadaniami.

\section{BIBLIOGRAFIA}

Gabryś A., Sudomir D., Kluczowe wyzwania w gospodarce odpadami komunalnymi $w$ krajach UE-11, Raport Ernst\&Young, Warszawa 2011.

Jerzmański J., Gospodarka odpadami komunalnymi - nowe zasady, „Przegląd Komunalny”, nr 9/2011.

Stelmasiak J. (red.), Prawo ochrony środowiska, Warszawa 2009.

Wierzbowski B., Rakoczy B., Prawo ochrony środowiska, Warszawa 2010.

Zyśk J., Rewolucja następuje powoli, „Odpady i Środowisko”, nr 1/2011.

31 Ustawa z dnia 1 lipca 2011 r. o zmianie ustawy o utrzymaniu czystości i porządku w gminach oraz niektórych innych ustaw, Dz. U. 2011 Nr 152, poz. 897. 
Zyśk J., W gminach po referendum, „Odpady i środowisko”, nr 2/2011. Zyśk J., Czy gminy będa w stanie zapanować nad odpadami?, „Prawo i odpady", nr 4/2011.

\section{Kontakt e-mil:}

martyna.kropiewnicka@op.pl 